\title{
Best Management Practices for Florida Citrus
}

\author{
Larry Parsons $^{1}$ and Brian Boman ${ }^{2}$
}

ADDITIONAL INDEX WORDS. nitrate, groundwater, fertilizer, nitrogen, irrigation

Summary. Best management practices (BMPs) started in Florida citrus (Citrus spp.) in the 1990s and have evolved to play a major role in production practices today. One of the earliest BMPs in Florida arose from concerns over nitrate-nitrogen concentrations in some surficial groundwater aquifers exceeding the 10 $\mathrm{mg} \cdot \mathrm{L}^{-1}$ drinking water standard. This occurred in an area of well-drained sandy soils known as the Central Florida Ridge that extends north and south through the central part of the Florida peninsula. State agencies could have used a strictly regulatory approach and restricted how much nitrogen growers could apply. Instead of setting arbitrary regulations, the agencies promoted a scientific-based BMP approach. A nitrogen BMP for Central Florida Ridge citrus was established, and research is now validating the earlier groundwater work on more grower field sites. The purpose of this BMP was to minimize the risk of leaching nitrates from fertilizer into the groundwater. Several important aspects of the BMP involve: 1) limiting the amount of nitrogen fertilizer applied at any one time, 2) increasing the frequency of fertilizer applications, 3) reducing fertilizer applications during the summer rainy season, and 4) managing irrigation to reduce leaching below the root zone. Since this Central Florida Ridge nitrogen BMP was established, major BMP actions to improve water quality and reduce the quantity of runoff water have taken place in the Indian River production area of Florida's east coast. BMPs continue to be set up in other parts of the state for a variety of plant and animal agricultural practices. In some cases, costshare funds have been provided to help implement BMPs. With voluntary BMPs, growers have scientifically based guidelines, a waiver of liability, and an avoidance of arbitrary regulations.

$\mathrm{F}$ lorida is the largest producer of citrus in the United States. Production area in the state was 748,555 acres in 2004. Even after damage from several recent hurricanes, Florida produced 7,588,000 tons of citrus in 2004-05. Most citrus is grown in central, southeastern, and southwestern Florida. Well-drained sandy soils extend north and south through the central part of the Florida peninsula. The primary area from Clermont to Lake Placid is commonly called the Central Florida Ridge(Jackson, 1991), and much of the state's citrus was grown there in the past. Soils in this area are classified as Entisols which are deep well-drained, highly permeable soils which have $>95 \%$ sand, $<3 \%$ clay, and $<2 \%$ organic matter. They have good aeration, but are inherently low in fertility, organic matter, and cation exchange capacity. Drainage often can be excessive in these soils. They are un-

${ }^{1}$ University of Florida, IFAS, Citrus Research and Education Center, 700 Experiment Station Road, Lake Alfred, FL 33850; to whom reprint requests should be addressed: e-mail: lrp@crec.ifas.ufl.edu

${ }^{2}$ University of Florida, IFAS, Indian River Research and Education Center, Ft. Pierce, FL 34945. able to hold much water or much of the mineral elements applied by fertilizers. Citrus is also grown on lowland soils with a sandy surface, which are classified as Alfisols or Spodosols. These are usually poorly drained soils near the coast and are referred to as flatwoods soils (Jackson et al., 1995). They commonly have drainage-impeding layers at less than $1 \mathrm{~m}$. Spodosols have an acidic hardpan of aluminum or iron and organic matter while Alfisols have a subsurface clay layer. The water table is commonly close to the surface, and these soils must be bedded and drained for successful citrus production.

Annual rainfall on the Florida peninsula is more than $1200 \mathrm{~mm}$, and because the Entisols of the Central Florida Ridge are very well drained,

$\begin{array}{llll}\begin{array}{l}\text { Units } \\ \text { To convert } \\ \text { U.S. to SI, } \\ \text { multiply by }\end{array} & \text { U.S. unit } & \text { SI unit } & \begin{array}{l}\text { To convert } \\ \text { SI to U.S., } \\ \text { multiply by }\end{array} \\ 0.4047 & \text { acre(s) } & \mathrm{ha} & 2.4711 \\ 1 & \mathrm{cbar} & \mathrm{kPa} & 1 \\ 0.3048 & \mathrm{ft} & \mathrm{m} & 3.2808 \\ 0.4536 & \mathrm{lb} & \mathrm{kg} & 2.2046 \\ 1.1209 & \mathrm{~b} / \mathrm{acre} & \mathrm{kg} \cdot \mathrm{ha}^{-1} & 0.8922 \\ 1 & \mathrm{ppm} & \mathrm{mg} \cdot \mathrm{L}^{-1} & 1 \\ 0.9072 & \text { ton(s) } & \mathrm{Mg} & 1.1023\end{array}$


applied agricultural chemicals including nitrogen $(\mathrm{N})$ fertilizers can easily leach into the groundwater. Loss of $\mathrm{N}$ by denitrification is low in these soils because they are generally well aerated. Because of their good drainage and susceptibility to leaching, these soils have been referred to as "vulnerable" (Jackson et al., 1995).

Best management practices for Florida citrus started in the 1990s because of concerns about increased nitrate concentrations in the shallow groundwater at some locations. This led to the Ridge Citrus Water Quality Project, which was set up to determine practical ways to lower groundwater nitrate concentrations (Graham and Alva, 1998). In recent years, other issues involving citrus and land management in relation to the environment led to the development of additional BMPs in other citrus growing regions of the state [Florida Department of Agriculture and Consumer Services (FDACS), 2006]. BMPs covering a variety of citrus-related topics and locations have now been established, and use of BMPs is becoming common in commercial production practices. The objective of this paper is to give a brief discussion of the background of Florida citrus BMPs. The experience of this important agricultural crop in Florida may prove instructive to other states that are considering the development of BMPs.

\section{Ridge Citrus Water Quality Project}

In the early 1990s, the U.S. Environmental Protection Agency found nitrate contamination in many Florida drinking water wells. Some urban and rural wells exceeded the nitrate maximum contaminant level (MCL), suggesting that agricultural and fertilizer application practices might be contributing to increased nitrate levels in the groundwater (Graham and Alva, 1998).

FDACS and the Florida Department of Environmental Protection (FDEP) carried out more detailed drinking water well analyses throughout the state. Out of the 3949 drinking water wells sampled, $2483(63 \%)$ had detectable nitrate levels and 584 (15\%) had nitrate-N levels above the MCL, which is $10 \mathrm{mg} \cdot \mathrm{L}^{-1}$. Of the 584 wells that exceeded the MCL statewide, $89 \%$ (519) were in the Central Florida Ridge citrus growing region. These wells were primarily in Highlands, Polk, and Lake counties (Graham and Alva, 1998).

Because of these groundwater quality surveys, FDACS formed a multi-agency Nitrate Study Committee in Oct. 1992 with members from FDACS, FDEP, the University of Florida-Institute of Food and Agricultural Sciences (UF-IFAS), and the Southwest Florida Water Management District. This committee recommended that a long-term research project (the Ridge Citrus Water Quality Project) be started to study the effects of alternative fertilization and water management practices on groundwater quality in the Central Florida Ridge citrus growing region. The objectives of the project were to: " 1$)$ generate baseline groundwater quality data from several commercial citrus groves in the Ridge citrus region ...;2) develop recommendations for alternative nutrient and water management practices ...to reduce off-site water quality impacts associated with citrus productions; and 3 ) assess the impacts of alternative management practices on groundwater quality, fruit yield and fruit quality" (Graham and Alva, 1998). Study sites in grower cooperator groves were chosen and instrumented. Baseline groundwater quality monitoring was begun in Sept. 1993.

Baseline monitoring at the Central Florida Ridge sites revealed that groves with water tables that were 1 to $2 \mathrm{~m}$ from the land surface did not show groundwater nitrate- $\mathrm{N}$ levels above the $10 \mathrm{mg} \cdot \mathrm{L}^{-1} \mathrm{MCL}$. This is presumably due to denitrification of $\mathrm{N}$ in the shallow groundwater. However, mature groves with water tables $3 \mathrm{~m}$ or more below the land surface often did have nitrate- $\mathrm{N}$ concentrations above the MCL in the top $6 \mathrm{~m}$ (monitored depth) of the aquifer. Hence, nitrate-N levels above the MCL were primarily an issue in the area of the vulnerable Central Florida Ridge soils and not in the poorly drained flatwoods areas. It has been suggested that denitrification occurs in the shallow flatwoods soils (Jackson et al. 1995), and hence high nitrate levels are less common there.

It has long been recognized that $\mathrm{N}$ is the primary fertilizer element affecting citrus yield (Koo, 1984). Prior to the 1990s, UF-IFAS N fertilizer recommendations for citrus were based on fruit production. The amount of $\mathrm{N}$ to be applied was based on $0.4 \mathrm{lb} \mathrm{N}$ per 90-lb box of fruit for orange (Citrus sinensis) and $0.3 \mathrm{lb} \mathrm{N}$ per $85-\mathrm{lb}$ box of grapefruit (C. paradisi). Based on earlier research, recommended $\mathrm{N}$ application rates were 100 to $300 \mathrm{lb} /$ acre $\mathrm{N}$ per year for oranges and 90 to 240 $\mathrm{lb} /$ acre $\mathrm{N}$ per year for grapefruit. It was noted that few irrigated Florida groves are apt to show benefit from more than $250 \mathrm{lb} /$ acre $\mathrm{N}$ per year (Koo, 1984), but there was no recommended upper limit on $\mathrm{N}$ application. During the 1980s and 1990s, if fertilizer containing $212 \mathrm{lb} /$ acre $\mathrm{N}$ were applied, that fertilizer material cost would represent about $15 \%$ to $17 \%$ of the total cultural costs in the Central Florida Ridge (R.P. Muraro, personal communication). Hence, $\mathrm{N}$ fertilizer was a relatively small proportion of the total production costs.

One possible approach to dealing with the issue of drinking water wells with nitrate levels above the MCL would be to regulate the amount of $\mathrm{N}$ fertilizer that could be applied to a given area. This regulatory approach was considered to be unacceptable because most growers were fertilizing according to practices (usually the UF-IFAS recommended levels) that they felt gave them optimum fruit production. Numerous meetings involving growers, university scientists, and regulatory agency personnel were held to discuss ways to reduce nitrate in the groundwater. Some growers felt strongly that they needed $300 \mathrm{lb} /$ acre $\mathrm{N}$ or more per year to grow a crop. Eventually, it was decided that BMPs should be developed for Central Florida Ridge citrus $\mathrm{N}$ fertilization.

BMPs must be environmentally protective, based on science, and economically viable. They must focus on real problems and solutions that work. Priorities for BMP implementation are to correct existing water quality and quantity problems and to minimize those water problems resulting from agricultural operations. BMP measures are not regulatory or enforcementbased; they are strictly voluntary. As part of BMP implementation, growers perform an environmental assessment of their operations. This process identifies which BMPs should be considered to achieve the greatest economic and environmental benefit. Adopted BMPs may be a single practice or grouping of practices that, when implemented, are designed to improve water quality. The BMPs that are selected for each parcel of land with a tax identification 
number are specified on a Notice of Intent to Implement and submitted to FDACS.

Once enrolled in the BMP program, landowners must maintain records and provide documentation regarding the implementation of all BMPs (e.g., fertilizer application dates and amounts, or design and construction details of a water control structure). One of the most innovative elements of the agricultural BMP program is the "presumption of compliance" with water quality standards to landowners who voluntarily implement adopted BMPs that have been verified to be effective by FDEP. This component provides a powerful incentive to encourage landowners to enroll in the BMP programs, since landowners are protected from cost recovery by the state if water quality standards are not met. This unique approach to addressing water quality concerns has been well received by environmental and agricultural communities alike and, as a result, is becoming the primary method for addressing water quality concerns.

Earlier discussions on Florida nitrate BMPs had been initiated in the leatherleaf fern (Rumobra adiantiformis) industry. Florida's leatherleaf fern industry has similarities to Central Florida Ridge citrus in that these ferns are grown on highly permeable soils and are a perennial crop. Up to 600 $\mathrm{lb} /$ acre N per year was used, but fertilizer cost represented only $1.6 \%$ of the estimated production costs. Nitrate and the pesticide aldicarb were found in the surficial aquifer at one fern production site (Stamps, 1996). A BMP program was developed for leatherleaf fern production that involved improved irrigation and fertilization practices (Stamps, 1995). Fern growers initially expressed reservations about the lower fertilizer rates that were proposed, but came to accept the BMPs when research in fern production areas showed that yields and fern quality were not affected. Scientists worked with leading growers who publicly expressed support due to their involvement in the field research.

Growers have complained that citrus BMPs create an excessive amount of regulation and record keeping. But BMPs are voluntary and growers do not have to sign up for them if they do not like them. State agencies could have arbitrarily regulated how much fertilizer a grower could apply, but this science-based BMP approach became the preferred choice. One of the major incentives for growers to enroll was that they would receive a "waiver of liability," protecting them from being sued by the state. The state was required to cover nitrate-related well cleanup costs if the grower was following the BMP. These costs could be substantial. Particularly in areas where groundwater nitrate issues were prevalent, the incentive for growers to enroll could be large. More recently, cost-sharing funds have become available to growers enrolled in BMP programs. These funds help implement specific BMP practices and act as an additional incentive to growers.

In 1994, the Florida legislature passed legislation with the intent of improving fertilizer management practices in a way that protected water resources while preserving agriculture. The goal was to develop BMPs and appropriate educational programs and incentives for agriculture and other major users of fertilizer. BMPs were defined as "practices or combinations of practices determined by research or field testing at representative sites to be the most effective and practicable methods of fertilization designated to meet nitrate groundwater quality standards, including economic and technological feasibility" (Kuhl et al., 1996). In 1995, a series of grower meetings were held to explain the BMP and get grower input. Around this time, citrus fertilizer recommendations were being reevaluated. The citrus $\mathrm{N}$ fertilization literature was reviewed (Davies, 1997a, 1997b), and much of the literature indicated that there was little yield advantage to using $\mathrm{N}$ rates above $200 \mathrm{lb} /$ acre. New recommended annual application rates for bearing trees were 100 to $200 \mathrm{lb} /$ acre (Tucker et al., 1995). Growers who were used to the earlier recommendation for oranges of $0.4 \mathrm{lb} \mathrm{N}$ per 90 -lb box of fruit produced resisted the proposed limits on the amount of $\mathrm{N}$ that could be used. Later, it was decided that until research-based BMPs could be developed, an "interim measure" would be adopted that would help lower groundwater nitrate- $\mathrm{N}$ to more acceptable levels (Kuhl et al., 1996). The interim measure was a series of recommendations that it was believed would reduce nitrate- $\mathrm{N}$ levels until the final BMP could be legally adopted.

To help establish the BMP, research was carried out in five commercial groves to determine the effect of changes in $\mathrm{N}$ and irrigation management on groundwater quality (Alva et al., 2003). Groundwater nitrate-N, fruit yield and quality, and leaf nutrient concentrations were monitored under the growers' normal management, and these measurements were continued for 4 years after improved irrigation and $\mathrm{N}$ fertilizer practices were implemented. Citrus in Florida is commonly fertilized with dry soluble or liquid fertilizers. Ammonium nitrate is commonly used, and nitrate can easily leach in vulnerable soils. The $\mathrm{N}$ management practices in the research study included slow release and watersoluble granular products, fertigation, and foliar application combined with fertigation. Irrigation management using tensiometers with set points of 10 and 15 cbar (which helped avoid overirrigation and leaching) was a major contributor to improved $\mathrm{N}$ uptake efficiency. After the BMP practices were started, there was a significant downward trend of nitrate concentration in the surficial groundwater over time (Graham and Alva, 1998). The most effective practice for decreasing surficial groundwater nitrate was a combination of foliar application of urea with fertigation. By using improved $\mathrm{N}$ and irrigation management, this study showed that good yields could be maintained and BMPs could be developed for citrus on vulnerable sandy soils (Alva et al., 2003).

The first Central Florida Ridge Nitrate BMP was adopted in Oct. 1996 and later amended in May 2001 and Oct. 2002. Several aspects of the final BMP included the following: 1) limiting the amount of $\mathrm{N}$ fertilizer applied at any one time, 2) increasing the frequency of fertilizer applications, 3 ) reducing fertilizer applications during the summer rainy season, and 4) managing irrigation to reduce leaching below the root zone. The primary goal was to reduce nitrate in the groundwater. For 4- to 7-year-old orange trees, the total $\mathrm{N}$ was limited to $200 \mathrm{lb} / \mathrm{acre}$ peryear. For broadcast applications, no more that $65 \mathrm{lb} /$ acre or $40 \mathrm{lb} /$ acre N could be used per application during the dry season in the spring or the wet season in the summer, respectively. With fertigation, applications could not exceed $15 \mathrm{lb} /$ acre $\mathrm{N}$ in the dry season. For trees more than 7 years old, total $\mathrm{N}$ could not exceed 240 
lb/acre. For particularly high yielding trees, rates could go up to 270 $\mathrm{lb} / \mathrm{acre} \mathrm{N}$ with certain conditions. This particular BMP is unique in that it puts specific limitations on how much $\mathrm{N}$ can be applied to citrus on vulnerable soils. Many other BMPs in other areas involve recommendations but few restrictions on what a grower could do. Some growers still felt that this Central Florida Ridge nitrate BMP was overly restrictive in the amount of $\mathrm{N}$ that could be applied. In spite of early resistance to accepting these limitations, about 108,000 acres of citrus in central Florida were enrolled in the program in 2005 (Boman, 2005). Studies are continuing at several other groves to see if the BMPs are improving groundwater nitrate levels, but more data needs to be collected before results are conclusive (A.W. Schumann, personal communication).

\section{Other citrus BMPs}

The BMP development process that started with groundwater nitrate issues evolved into other agricultural BMPs. In 1998, citrus growers started to develop BMPs for the Indian River Lagoon (IRL) production area on the east coast of Florida, an important grapefruit growing region. The IRL consists of terrestrial, wetland, and estuarine ecosystems that create a complex ecosystem with high habitat diversity. The estuary has some of the greatest species diversity of any estuary in North America, but it is threatened by increasing residential and commercial development. Extensive agricultural and urban drainage projects have altered the timing (e.g., excess wet season flows, inadequate dry season flows), quality, and volume of freshwater entering the lagoon (Boman et al., 2003). In this area, intense thunderstorms and hurricanes can produce extensive rainfall. This excess water needs to be drained to protect urban and agricultural areas from flooding.

In Dec. 1998, growers began the development of BMPs for IRL citrus groves. BMPs were defined as on-farm practices that reach high production efficiency while limiting off-site effects of agricultural operations and also maintain economic viability. BMPs in the IRL were set up specifically to deal with water volume, sediment transport, pesticide and nutrient movement into receiving water bodies, and aquatic plants (Boman, 2003).
In 1999, the Florida Legislature passed the Florida Watershed Restoration Act. This act designates FDEP to develop total maximum daily loads (TMDLs) for impaired waters of the state. TMDLs are the maximum amount of a pollutant that a water body can receive and still meet water quality standards established by the Clean Water Act of 1972. FDEP coordinates with several agencies including FDACS and the water management districts to achieve water standards. FDACS deals with non-point source pollution from agriculture and works with stakeholders to develop sciencebased BMPs for agricultural land uses. By working with FDACS and other agencies, growers hoped to minimize regulation, legislation, and litigation regarding TMDLs in the IRL. The program developed an extensive BMP manual (Boman et al, 2000), held a number of on-farm demonstrations, and carried out worker training and public education programs.

In June 2002, the Indian River area citrus BMP rule was adopted for groves located in several counties in the Indian River area. By 2005, more than 193,000 acres were enrolled in the BMP program. This approaches $95 \%$ adoption for the total citrus acreage in the area, but updated figures are needed due to some land use changes brought about by hurricanes, diseases, and urbanization. After several years of development, BMPs were also established for the Peace River and Manasota basins in central Florida. These BMP manuals provide guidelines for implementing practices that will reduce runoff from groves. In 2004, gulf-coast (Gulf of Mexico coast) growers in southwestern Florida started to develop BMPs for their region. Primary issues in this area dealt with water resources, erosion control, and sediment, pest and nutrient management (Boman, 2005). BMPs for the gulf-coast area were formally adopted in 2006. BMP manuals for all the citrus regions can be found online (FDACS, 2006).

BMPs are considered to be voluntary, but it has been pointed out that in areas where a basin management action plan (BMAP) has been established, growers who choose not to adopt the voluntary BMP plan must self-monitor and show that they do not pollute. Selfmonitoring can be expensive and is not necessarily an affordable option. When a BMAP is in place, it has been argued that the BMP shifts from a voluntary to a quasi-regulatory situation.

While BMPs were initially resisted by a number of growers, a fair number have come to accept BMPs and realize that these practices have some advantages. Many now feel that following BMPs is "the right thing to do." Particularly for fresh fruit growers, using BMPs makes good business sense and helps them market fruit in certain European countries. Cost share programs have also helped implement practices that promote better application efficiency of pesticides and fertilizer.

\section{Summary}

BMPs must be science-based if possible, environmentally protective, and economically viable. They must focus on real problems and solutions. The priority is to correct or minimize water quality and quantity problems coming from agricultural operations. BMPs are not regulatory or based on enforcement. In most cases, they are voluntary. When enrolled in a BMP program, landowners must document the implementation of the BMP and maintain records (Boman, 2005).

One of the important aspects in BMP adoption is the granting of the "presumption of compliance" with water quality standards to those who implement the BMPs. This is a strong incentive to enroll because landowners are then protected from cost recovery by the state if water quality standards are not met. Growers who enroll in the BMP programs also become eligible for cost sharing funds to implement certain BMP practices (Boman, 2005). Some of these funds have been used to help purchase variable rate fertilizer spreaders and other precision application equipment.

In the past 15 years, BMPs have been developed and implemented throughout much of the Florida citrus industry. The development of these BMPs has involved numerous hours of discussion by growers, agencies, and other affected parties. Growers have interacted with state agencies to develop BMPs that fit their particular region and have adopted these BMPs because they are non-regulatory and voluntary. Other states dealing with land, environmental, agricultural, and water quality issues might benefit from examining the BMP process that still is continuing to evolve in Florida. 


\section{Literature cited}

Alva, A.K., S. Paramasivam, W.D. Graham, and T.A. Wheaton. 2003. Best nitrogen and irrigation management practices for citrus production in sandy soils. Water Air Soil Pollution 143:139-154.

Boman, B.J., P.C. Wilson, and J.W. Hebb (Eds.). 2000. Water quality/quantity BMPs for Indian River area citrus groves. Florida Dept. of Environ. Protection, Tallahassee.

Boman, B.J., P.C. Wilson, and J.W. Hebb. 2003. The Indian River citrus BMP development and implementation process. Amer. Soc. Agr. Eng. Paper No. 032082.

Boman, B. 2005. ABCs of BMPs. Citrus Ind. $86(3): 24-25$

Davies, F.S. 1997a. Nitrogen fertilization research on mature, bearing orange trees -1880 to 1979 . Citrus Ind. 78(5):41-45.

Davies, F.S. 1997b. Nitrogen fertilization research on mature bearing citrus trees, 1980 to present. Citrus Ind. 78(6):38-39.

Florida Department of Agriculture and Consumer Services. 2006. Office of Agricultural Water Policy. Best management practices. 25 Apr. 2006. <http://www.floridaagwaterpolicy.com/BestManagementPractices. html>.

Graham, W. and A. Alva. 1998. Ridge Citrus Water Quality Project. Annual progress report (1997-1998). Univ. of Florida, Inst. Food Agr. Sci., Gainesville, and Univ. of Florida, Citrus Res. Educ. Ctr., Lake Alfred.

Jackson, L.K. 1991. Citrus growing in Florida. 3rd ed. Univ. of Florida Press, Gainesville.

Jackson, L.K., A.K. Alva, D.P.H. Tucker, and D.V. Calvert. 1995. Factors to consider in developing a nutrition program, p. 3-11. In: D.P.H. Tucker, A.K. Alva, L.K. Jackson, and T.A. Wheaton (eds.). Nutrition of Florida citrus trees. Univ. of Florida SP169.

Koo, R.C.J. (ed.). 1984. Recommended fertilizers and nutritional sprays for citrus. Agri. Expt. Sta., Inst. Food Agr. Sci., Univ. of Florida Bul. 536D.

Kuhl, K.A., R.J. Budell, and B.L. McNeal. 1996. Nitrogen BMP program implementation. Soil Crop Sci. Soc. Fla. Proc. $55: 67-70$.

Stamps, R.H. 1995. Irrigation and nutrient management practices for commercial leatherleaf fern production in Florida. 25 Apr. 2006. <http:www.floridaagwaterpolicy. com/PDFs/BMPs/LeatherLeafFern.pdf>.

Stamps, R.H. 1996. Developing improved irrigation and nutrient management practices: A case study-Leatherleaf fern. Soil Crop Sci. Soc. Fla. Proc. 55:71-73.

Tucker, D.P.H., A.K. Alva, L.K. Jackson, and T.A. Wheaton (eds.). 1995. Nutrition of Florida citrus trees. Univ. of Florida, SP169. 